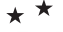

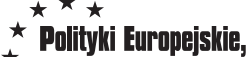

$\star$ Finanse i Marketing

$\star \star \star 15$ (64) 2016

Adam Andrzejuk

Szkola Glówna Gospodarstwa Wiejskiego w Warszawie

\title{
Stopy zwrotu na rynku kapitałowym w kontekście fuzji i przejęć - studium przypadku
}

\section{RATE OF RETURN FROM CAPITAL MARKETS IN THE CONTEXT OF MERGERS AND ACQUISITIONS - CASE STUDY}

$W$ artykule została przedstawiona analiza wpływu przejęcia spółki TVN SA przez Scripps Networks Interactive Inc na zyski inwestorów trzymajacych akcje $w$ różnych okresach czasowych. Z uwagi na fakt, że obie spótki reprezentuja branżę dóbr informacyjnych, na poczqtku została zaprezentowana definicja oraz główne cechy tej branży. Dobra informacyjne często charakteryzuja się krótkim cyklem życia produktu. $Z$ tego powodu spótki działajace $w$ tej branży często stoja przed dylematem czy samodzielnie tworzyć produkt czy té przejać już gotowa firme posiadajaca taki produkt. Samodzielne tworzenie dobra informacyjnego pociaga za soba wysokie ryzyko kosztów bezpowrotnie utraconych jeśli produkt okaże się klapq. Przejęcie spótki z gotowym produktem często wiąze się z zapłaceniem premii za przejęcie. Głównym założeniem jest hipoteza efektywności rynków. Celem artykułu było zbadanie jak wezwanie do sprzedaży akcji spótki branży dóbr informacyjnych notowanej na giełdzie papierów wartościowych, wplynęto na zyski inwestorów trzymajacych akcje w różnych okresach czasowych, oraz jaka premię za przejęcie musiała zaptacić spótka przejmujaca. Postużono się metoda średnich skumulowanych nadzwyczajnych stóp zwrotu.

Słowa kluczowe: dobra informacyjne, fuzje, przejęcia, koncentracja przedsiębiorstw, stopy zwrotu

Wstęp

Rozwój Internetu jako medium dystrybucji danych i informacji w postaci oprogramowania, zdjęć, muzyki, filmów stworzył całkowicie nowe szanse dla branży dóbr informacyjnych. Ale czym właściwie są dobra informacyjne? Nad tym problemem pochylili się Varian i Shapiro definiując dobra informacyjne jako wszystko to co można zapisać w wersji cyfrowej. Nie ma wymogu, że informacja ta musi już być zapisane na jakimś nośniku, chodzi przede wszystkim o możliwość zapisu [Varian, 1998].

Dobra informacyjne posiadają także swoistą charakterystykę. Varian wyróżnia trzy główne cechy dóbr informacyjnych:

1. Dobra doświadczeniowe (experience goods) - nie da się bezpośrednio dotknąć dobra informacyjnego, aby je poznać trzeba je doświadczyć. Nabywając dobra 
trwałe, wiemy, że posiadają one pewną użyteczność. Dla przykładu wiemy, że nabywając talerze, chociażby drogą przez Internet i w sytuacji gdy nie jesteśmy w stanie ich dotknąć, to możemy się spodziewać, że będziemy na nich mogli spożywać posiłki. W przypadku dóbr informacyjnych nie mamy takiego komfortu. Już pierwsze doświadczenie tych dóbr jest jednocześnie ich konsumpcją.

2. Niskie koszty marginalne - wytworzenie dóbr informacyjnych może pochłaniać olbrzymie kwoty jak to ma miejsce w produkcjach filmów hollywoodzkich, ale już wytworzenie kolejnej kopii, biorąc pod uwagę dzisiejszy stan technik cyfryzacji, jest prawie darmowe. W tym sensie można powiedzieć, że dobra informacyjne cechują się wysokimi kosztami stałymi, będącymi jednocześnie kosztami utopionymi (sunk cost), i znikomymi kosztami marginalnymi.

3. Dobro publiczne - dobra informacyjne moga posiadać cechy dóbr publicznych. Ze względu na niskie koszty marginalne, ich konsumpcja nie uszczupla podstawowego zasobu dobra. Bywają też sytuacje, że niemożliwe staje się ich ograniczenie w konsumpcji.

Internet i technika cyfrowa stworzyły poprzez redukcje kosztów marginalnych, nowe możliwości i szanse dla firm zajmujących się produkcją i handlem dobrami informacyjnymi, takie jak: łączenia zawartości poprzez sprzedaż wiązaną, licencjonowanie, subskrypcje, elektroniczny wynajem, różnicowanie cenowe, różnicowanie produktowe, efekty uwięzienia i inne mechanizmy nieobecne w świecie dóbr trwałych [Bakos et al, 1997]. Powyższe strategie ekonomiczne wytworzyły bardzo konkurencyjne środowisko w którym przychodzi działać przedsiębiorstwom branży dóbr informacyjnych, a motywy konsolidacji kapitałowej mogą być całkowicie odmienne niż w przypadku firm działających w branży dóbr fizycznych. To zjawisko obserwowane jest często w branży startupowej, gdzie powodem do konsolidacji jest nie tylko sam fakt poszerzenia rynku odbiorców końcowych, ale też chęć nabycia nowego dobra informacyjnego w decyzji make-or-buy. Duże wyzwanie stoi przed inwestorami posiadającymi akcje spółek tej branży. Wycena własności intelektualnej takiej jak dobra informacyjne, wraz $\mathrm{z}$ możliwymi do zastosowania przez firmę strategiami ekonomicznymi nie należy do łatwych. Często wychodzi na to, że zamiast tworzyć dobro informacyjne od początku, o wiele mnie ryzykownym działaniem wydaje się zakup już ugruntowanej pozycji konkurenta. Jest to jeden $\mathrm{z}$ motywów zarządów i właścicieli spółek angażujących się w fuzje i przejęcia.

Głównym problemem niniejszego artykułu było zbadanie jak wezwanie do sprzedaży akcji spółek branży dóbr informacyjnych notowanych na giełdzie papierów wartościowych, wpłynęło na zyski inwestorów trzymających akcje w różnych okresach czasowych. A także jaką premię za przejęcie musiała zapłacić spółka przejmująca. W tym celu stworzono następującą hipotezę: Wezwania do sprzedaży akcji spółek publicznych powiększają zyski inwestorów giełdowych, gdyż powodują zwiększanie się stóp zwrotu $\mathrm{z}$ akcji przedsiębiorstw przejmowanych jeszcze przed ogłoszeniem wezwania. Co jest zgodne z teorią efektywności informacyjnej rynków kapitałowych, i jednocześnie zgodne z obserwacjami, że inwestorzy giełdowi dyskontują fakty znane, a obstawiają hipotezy przewidywane. Usystematyzowane i oparte na pewnych założeniach 
rozwiązanie teoretyczne, przybliżające do odpowiedzi na pytania, czy i w jakim stopniu rynki są efektywne, zaproponował w 1970 roku E. F. Fama [Kamiński et al., 2010]. W myśl teorii efektywności, spółki notowane na efektywnych rykach giełdowych są wyceniane $\mathrm{z}$ uwzględnieniem wszystkich publicznie dostępnych informacji o charakterze zarówno technicznym, jak i fundamentalnym [Kamiński et al. za Gabryś, 2010]. Teoretycznie inwestorzy kupujący lub sprzedający walory na efektywnym rynku nie powinni móc osiagnąć ponadprzeciętnych stóp zwrotu, ponieważ papiery wartościowe są zawsze wycenione na właściwym poziomie [Kamiński et al. za Cunningham, 2010].

\section{Analiza}

W celu zweryfikowania powyższej hipotezy należało obliczyć stopy zwrotu dla inwestorów w różnych odstępach czasowych. W tym celu określono grupę badawczą. Zdecydowano się na wyszukanie spółek publicznych sektora dóbr informacyjnych zgodnych $\mathrm{z}$ wyżej omówioną definicją, $\mathrm{z}$ amerykańskiego indeksu S\&P500, oraz polskiego indeksu WIG. Z uwagi na fakt, że żaden z wyżej wymienionych indeksów nie określa oficjalnie branży dóbr informacyjnych, spółek zajmujących się handlem lub produkcją takich dóbr poszukiwano w sektorach mediów oraz informatyki. W przypadku indeksu S\&P500 wyodrębniono 44 spółki działające w branży dóbr informacyjnych. W przypadku indeksu WIG wyodrębniono 37 spółek w tej samej branży. Jak wynika z analizy charakterystyki działalności poszczególnych spółek z rynku amerykańskiego i polskiego, oba sektory stanowią najbardziej przybliżony odpowiednik spółek zajmujących się produkcją i handlem dobrami informacyjnymi. 
Tabela 1. Spółki sektora mediów oraz informatyki z indeksu S\&P500

\begin{tabular}{|c|c|c|c|c|}
\hline $\operatorname{Lp}$ & S\&P500 & Sektor & Giełda & $\begin{array}{c}\text { Kapitalizacja } \\
15.10 .2015 \\
\end{array}$ \\
\hline 1 & Adobe Systems Inc & Application Software & NASDAQ & $41,80 \mathrm{~B}$ \\
\hline 2 & Autodesk Inc & Application Software & NASDAQ & $11,62 \mathrm{~B}$ \\
\hline 3 & Oracle Corporation & Application Software & NYSE & $158,90 \mathrm{~B}$ \\
\hline 4 & Symantec Corporation & Application Software & NASDAQ & 13,99B \\
\hline 5 & Teradata Corporation & Application Software & NYSE & $4,02 B$ \\
\hline 6 & CBS Corporation & Broadcasting \& Cable TV & NYSE & $20,65 B$ \\
\hline 7 & Comcast Corporation & Broadcasting \& Cable TV & NASDAQ & $150,44 B$ \\
\hline 8 & Discovery Communications & Broadcasting \& Cable TV & NASDAQ & $11,70 \mathrm{~B}$ \\
\hline 9 & Scripps Networks Interactive Inc. & Broadcasting \& Cable TV & NYSE & $7,10 \mathrm{~B}$ \\
\hline 10 & Time Warner Inc. & Broadcasting \& Cable TV & NYSE & $57,93 B$ \\
\hline 11 & Viacom Inc. & Broadcasting \& Cable TV & NASDAQ & $18,85 \mathrm{~B}$ \\
\hline 12 & The Walt Disney Company & Broadcasting \& Cable TV & NYSE & $178,46 \mathrm{~B}$ \\
\hline 13 & Activision Blizzard & Home Entertainment Softu & NASDAQ & $24,07 \mathrm{~B}$ \\
\hline 14 & Electronic Arts & Home Entertainment Softu & NASDAQ & $22,00 \mathrm{~B}$ \\
\hline 15 & News Corporation & Publishing & NASDAQ & $8,17 \mathrm{~B}$ \\
\hline 16 & Tegna & Publishing & NYSE & $5,67 \mathrm{~B}$ \\
\hline 17 & Twenty-First Century Fox & Publishing & NASDAQ & $56,75 B$ \\
\hline 18 & CA Inc. & Systems Software & NASDAQ & $12,64 \mathrm{~B}$ \\
\hline 19 & Microsoft Corporation & Systems Software & NASDAQ & $373,35 \mathrm{~B}$ \\
\hline 20 & Red Hat Inc. & Systems Software & NYSE & $13,73 B$ \\
\hline 21 & Interpublic Group & Advertising & NYSE & $8,56 \mathrm{~B}$ \\
\hline 22 & Omnicom Group & Advertising & NYSE & $17,22 \mathrm{~B}$ \\
\hline 23 & Amazon.com Inc & Internet Retail & NASDAQ & $254,82 B$ \\
\hline 24 & TripAdvisor & Internet Retail & NASDAQ & $12,06 \mathrm{~B}$ \\
\hline 25 & Akamai Technologies Inc & Internet Software \& Service & NASDAQ & $12,55 \mathrm{~B}$ \\
\hline 26 & Automatic Data Processing & Internet Software \& Service & NASDAQ & $39,61 B$ \\
\hline 27 & Citrix Systems & Internet Software \& Service & NASDAQ & $11,82 \mathrm{~B}$ \\
\hline 28 & eBay Inc. & Internet Software \& Service & NASDAQ & $29,23 B$ \\
\hline 29 & Equinix & Internet Software \& Service & NASDAQ & $16,13 B$ \\
\hline 30 & Facebook & Internet Software \& Service & NASDAQ & $265,05 B$ \\
\hline 31 & Fidelity National Information Services & Internet Software \& Service & NYSE & $19,54 \mathrm{~B}$ \\
\hline 32 & Fiserv Inc & Internet Software \& Service & NASDAQ & $21,33 B$ \\
\hline 33 & Alphabet Inc & Internet Software \& Service & NASDAQ & $456,39 B$ \\
\hline 34 & Intuit Inc. & Internet Software \& Service & NASDAQ & $25,07 \mathrm{~B}$ \\
\hline 35 & Mastercard Inc. & Internet Software \& Service & NYSE & $107,58 \mathrm{~B}$ \\
\hline 36 & NetApp & Internet Software \& Service & NASDAQ & $9,99 \mathrm{~B}$ \\
\hline 37 & Netflix Inc. & Internet Software \& Service & NASDAQ & $46,96 \mathrm{~B}$ \\
\hline 38 & Paychex Inc. & Internet Software \& Service & NASDAQ & $17,86 \mathrm{~B}$ \\
\hline 39 & Salesforce.com & Internet Software \& Service & NYSE & $50,34 \mathrm{~B}$ \\
\hline 40 & Total System Services & Internet Software \& Service & NYSE & $8,83 \mathrm{~B}$ \\
\hline 41 & Verisign Inc. & Internet Software \& Service & NASDAQ & $8,44 \mathrm{~B}$ \\
\hline 42 & Visa Inc. & Internet Software \& Service & NYSE & $180,52 B$ \\
\hline 43 & Western Union Co & Internet Software \& Service & NYSE & 9,57B \\
\hline 44 & Yahoo Inc. & Internet Software \& Service & NASDAQ & $30,21 B$ \\
\hline
\end{tabular}

Źródło: opracowanie własne na podstawie danych z Morningstar, Inc. 
Tabela 2. Spółki sektora mediów oraz informatyki z indeksu WIG

\begin{tabular}{|c|c|c|c|c|}
\hline Lp & WIG & Sektor & Giełda & $\begin{array}{c}\text { Kapitalizacja } \\
15.10 .2015\end{array}$ \\
\hline 1 & CYFRPLSAT & Media & Warsaw & $15,99 \mathrm{~B}$ \\
\hline 2 & AGORA & Media & Warsaw & $517,17 \mathrm{M}$ \\
\hline 3 & WIRTUALNA & Media & Warsaw & $1,11 \mathrm{~B}$ \\
\hline 4 & SMT & Media & Warsaw & $192,47 \mathrm{M}$ \\
\hline 5 & ATMGRUPA & Media & Warsaw & $289,99 \mathrm{M}$ \\
\hline 6 & KINOPOL & Media & Warsaw & $272,54 \mathrm{M}$ \\
\hline 7 & K2INTERNT & Media & Warsaw & $32,68 \mathrm{M}$ \\
\hline 8 & 4FUNMEDIA & Media & Warsaw & $20,76 \mathrm{M}$ \\
\hline 9 & MUZA & Media & Warsaw & $9,01 \mathrm{M}$ \\
\hline 10 & ASSECOPOL & Informatyka & Warsaw & $4,56 \mathrm{~B}$ \\
\hline 11 & CDPROJEKT & Informatyka & Warsaw & $2,54 \mathrm{~B}$ \\
\hline 12 & COMARCH & Informatyka & Warsaw & $980,07 \mathrm{M}$ \\
\hline 13 & MEDICALG & Informatyka & Warsaw & $715,29 \mathrm{M}$ \\
\hline 14 & ASSECOBS & Informatyka & Warsaw & $484,56 \mathrm{M}$ \\
\hline 15 & COMP & Informatyka & Warsaw & $334,38 \mathrm{M}$ \\
\hline 16 & ATM & Informatyka & Warsaw & $336,90 \mathrm{M}$ \\
\hline 17 & LIVECHAT & Informatyka & Warsaw & $897,39 \mathrm{M}$ \\
\hline 18 & CIGAMES & Informatyka & Warsaw & $324,92 \mathrm{M}$ \\
\hline 19 & ASSECOSEE & Informatyka & Warsaw & $513,23 \mathrm{M}$ \\
\hline 20 & SYGNITY & Informatyka & Warsaw & $110,54 \mathrm{M}$ \\
\hline 21 & QUMAK & Informatyka & Warsaw & $109,35 M$ \\
\hline 22 & ATENDE & Informatyka & Warsaw & $92,31 \mathrm{M}$ \\
\hline 23 & ELZAB & Informatyka & Warsaw & $244,96 \mathrm{M}$ \\
\hline 24 & WINDMOBIL & Informatyka & Warsaw & $98,65 \mathrm{M}$ \\
\hline 25 & WASKO & Informatyka & Warsaw & $175,99 \mathrm{M}$ \\
\hline 26 & MCLOGIC & Informatyka & Warsaw & $75,36 \mathrm{M}$ \\
\hline 27 & CUBEITG & Informatyka & Warsaw & $45,21 \mathrm{M}$ \\
\hline 28 & IVMX & Informatyka & Warsaw & $74,36 \mathrm{M}$ \\
\hline 29 & INDATA & Informatyka & Warsaw & $52,01 \mathrm{M}$ \\
\hline 30 & SIMPLE & Informatyka & Warsaw & $40,34 \mathrm{M}$ \\
\hline 31 & OPTEAM & Informatyka & Warsaw & $72,27 \mathrm{M}$ \\
\hline 32 & TALEX & Informatyka & Warsaw & $53,70 \mathrm{M}$ \\
\hline 33 & NTTSYSTEM & Informatyka & Warsaw & $33,24 \mathrm{M}$ \\
\hline 34 & BETACOM & Informatyka & Warsaw & $21,15 \mathrm{M}$ \\
\hline 35 & LSISOFT & Informatyka & Warsaw & $14,93 \mathrm{M}$ \\
\hline 36 & PROCAD & Informatyka & Warsaw & $14,97 \mathrm{M}$ \\
\hline 37 & TVN & Media & Warsaw & $6,78 \mathrm{~B}$ \\
\hline
\end{tabular}

Źródło: opracowanie własne na podstawie danych z gpw.pl

Kolejnym etapem poszukiwania było znalezienie spółek uczestniczących w transakcji fuzji lub przejęcia. Tu z pomocą przyszła niedawna transakcja nabycia akcji polskiej spółki TVN SA, notowanej na warszawskiej giełdzie papierów wartościowych, przez Scripps Networks Interactive Inc ze Stanów Zjednoczonych notowanej na NYSE, która odbiła się głośnym echem w świecie finansów. Wezwanie do zapisów na sprzedaż akcji spółki TVN SA zostało ogłoszone dnia 6 lipca 2015 roku. Akcje objęte wezwaniem 
były nabywane po cenie w wysokości 20,00 zł za jedną Akcję. Cena ta była jednakowa dla wszystkich Akcji Spółki.

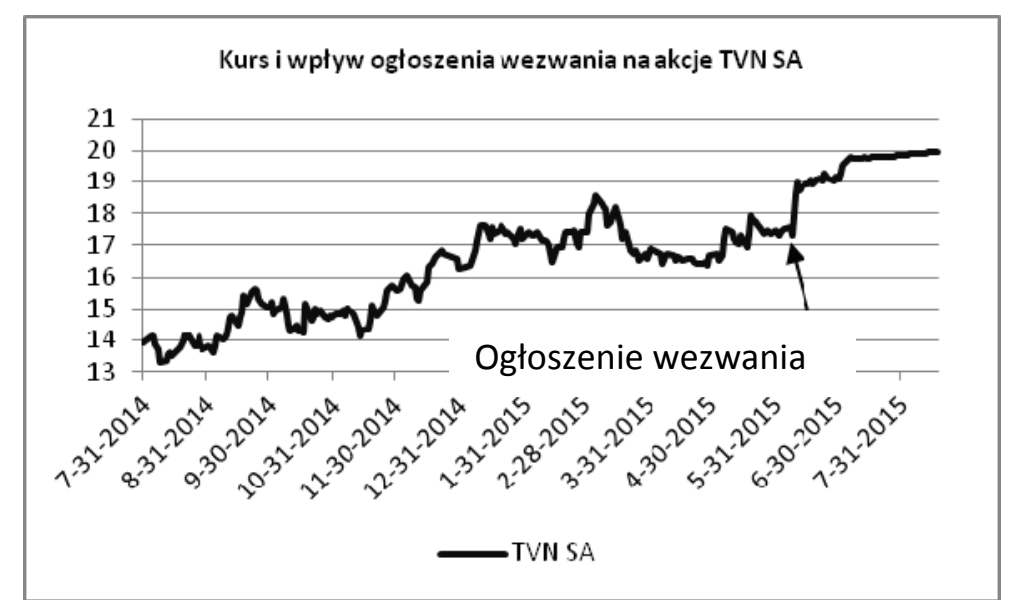

Wykres 1. Wpływ ogłoszenia wezwania na kurs akcji spółki TVN SA Źródło: opracowanie własne na podstawie danych z gpw.pl

Na wykresie 1 ukazano kształtowanie się kursu akcji spółki TVN SA w okresie od lipca 2014 roku do lipca 2015 roku. Za pomoca strzałki wskazany został czas ogłoszenia wezwania do zapisów na sprzedaż akcji spółki TVN SA. W dalszych badaniach przeprowadzono dogłębną analizę wpływu przejęcia spółki TVN SA na stopy zwrotu dla inwestorów giełdowych. W celu realizacji tego zadania podjęto następujące działania:

1. Zdefiniowano okres badań.

2. Obliczono normalne oczekiwane stopy zwrotu $\mathrm{z}$ akcji.

3. Obliczono nadzwyczajne stopy zwrotu $\mathrm{z}$ akcji.

4. Obliczono nadzwyczajne skumulowane stopy zwrotu $\mathrm{z}$ akcji .

Ad 1. Dzień ogłoszenia wezwania określony jest jako dzień zerowy w tym przypadku jest to 6 lipca 2015 roku. Różni autorzy w swoich badaniach przyjmują różne okresy. M. Firth przyjmuje w swoich badaniach okres \pm 40 dni, C.Loderer i H. Zimmermann przyjmują natomiast okres \pm 10 miesięcy [Kraciuk za Neumann, 1994]. Jak ukazano na rysunku 1, długość badanego okresu została przyjęta na 30 dni przed i po ogłoszeniu wezwania do sprzedaży akcji, jak również okresy 10 dni i 5 dni. 


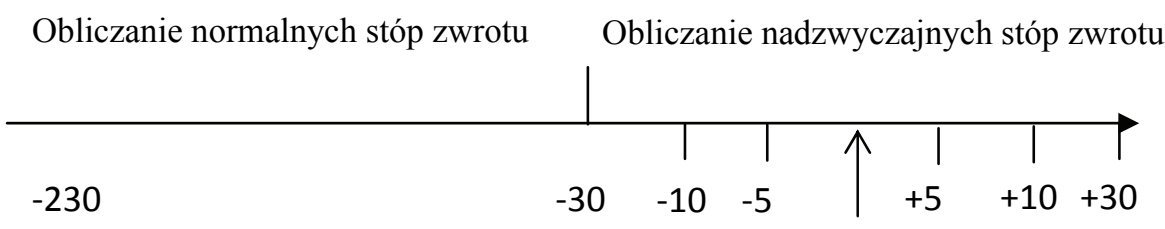

Wezwanie do sprzedaży akcji

Rysunek 1. Okresy czasu przyjęte do obliczania normalnych i nadzwyczajnych stóp zwrotu Źródło: J.Kraciuk na podstawie [Neuman 1994].

Ad 2. W celu obliczenia normalnej stopy zwrotu, przyjęto za Neumanem okres (-230) (-30) dni od dnia zerowego [Kraciuk za Neuman 1994]. Ponadto, posłużono się wzorem na tzw. logarytmiczną stopę zwrotu, ma to na celu wykorzystanie m.in. właściwości addytywnych funkcji wykładniczych. Jednocześnie, zastosowano model średnich skorygowanych polegający na obliczeniu rzeczywistych logarytmicznych stóp zwrotu dla okresu 200 dni poprzedzających okres 30 dni przed wezwaniem do sprzedaży akcji.

$$
R_{j t=\ln \left(P_{t-1}\right)}
$$

Gdzie $P_{t}$ - stanowi cenę waloru w dniu t, a $P_{t-1}$ cenę tego waloru w dniu poprzednim.

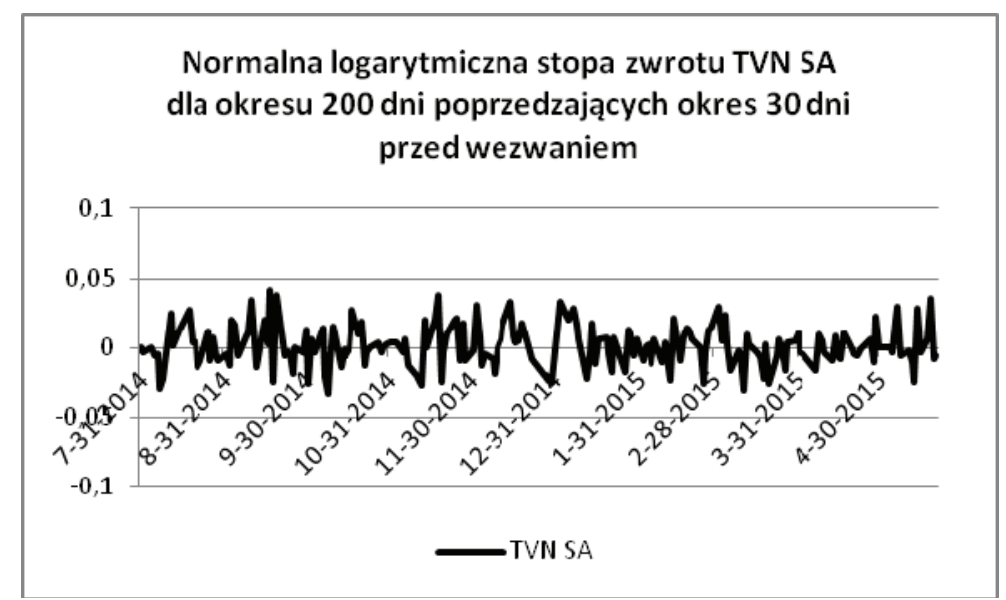

Wykres 2. Normalna stopa zwrotu dla akcji spółki TVN SA

Źródło: opracowanie własne na podstawie danych z gpw.pl 


\begin{tabular}{|c|c|}
\hline \multicolumn{2}{|c|}{$\begin{array}{c}\text { Staystyka opisowa dla normalnych } \\
\text { logarytmicznych stóp zwrotu akcji spółki } \\
\text { TVN SA }\end{array}$} \\
\hline Średnia & 0,001185915 \\
\hline Błąd standardowy & 0,001052403 \\
\hline Odchylenie standardowe & 0,014883226 \\
\hline Wariancja próbki & 0,00022151 \\
\hline Kurtoza & 0,05290322 \\
\hline Skośność & 0,275459219 \\
\hline Zakres & 0,074820883 \\
\hline Maksimum & 0,041382497 \\
\hline Suma & 0,237183058 \\
\hline Licznik & 200 \\
\hline
\end{tabular}

Następnie dokonano obliczenia średniej logarytmicznej stopy zwrotu dla spółki TVN SA dla okresu poprzedzającego okres 30 dni przed wezwaniem do sprzedaży.

$$
\hat{R}_{j}=* \sum_{t=-2100}^{t=-81} R_{j t}
$$

Gdzie $\tilde{R}_{j}$ - stanowi średnią logarytmiczną stopę zwrotu j-tej spółki w okresie 200 dni poprzedzających badany okres obliczoną według modelu średnich skorygowanych. Średnia logarytmiczna stopa zwrotu TVN w okresie 200 dni poprzedzających badany okres wyniosła 0,001185915 .

Ad 3. W kolejnym kroku obliczono nadzwyczajne stopy zwrotu dla akcji TVN SA w każdym analizowanym dniu. Stanowi ją różnica między stopą zwrotu rzeczywiście zaobserwowaną $\mathrm{w}$ danym dniu a normalną stopą zwrotu obliczona przy zastosowaniu modelu średnich skorygowanych.

$$
r_{j t}=R_{j t}-\hat{n}_{j}
$$

Gdzie $r_{j t}$ - stanowi nadzwyczajna stopę zwrotu z akcji j w czasie $\mathrm{t}$ 


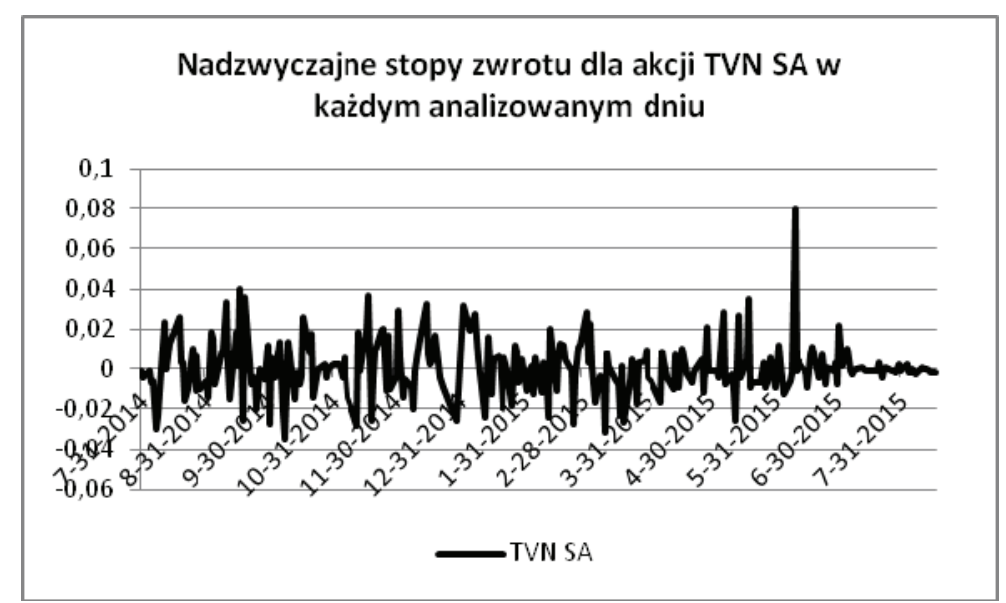

Wykres 3. Nadzwyczajne stopy zwrotu dla akcji spółki TVN SA

Źródło: opracowanie własne na podstawie danych z gpw.pl

Na wykresie 3 przedstawiono obliczenia nadzwyczajnych stóp zwrotu dla każdego dnia z przedziału \pm 30 dni względem daty ogłoszenia wezwania. Największy wzrost nadzwyczajnych stóp zwrotu można zaobserwować jeszcze przed ogłoszeniem wezwania. Po ogłoszeniu wezwania zakres wahań kursów akcji ulega znacznemu spłaszczeniu.

\begin{tabular}{lr}
\hline \multicolumn{2}{c}{$\begin{array}{c}\text { Staystyka opisowa dla } \\
\text { nadzwyczajnych stóp zwrotu dla akcji } \\
\text { TVN SA }\end{array}$} \\
\hline Średnia & 0,000176 \\
Błąd standardowy & 0,000878 \\
Odchylenie standardowe & 0,014179 \\
Wariancja próbki & 0,000201 \\
Kurtoza & 3,687345 \\
Skośność & 0,898695 \\
Zakres & 0,114053 \\
Maksimum & 0,079429 \\
Suma & 0,045862 \\
Licznik & 260 \\
Źródło: opracowanie własne na podstawie \\
danych z gpw.pl
\end{tabular}

Ad 4. Finalnym etapem badań było obliczenie skumulowanych nadzwyczajnych stóp zwrotu dla okresu od $\mathrm{t}=-30$ do $\mathrm{t}=30$, od $\mathrm{t}=-10$ do $\mathrm{t}=10$ oraz od $\mathrm{t}=-5$ do $\mathrm{t}=5$.

$$
r_{t}=\sum_{t=-10}^{30} r_{j t} \quad \sum_{t}^{10} r_{i t} \quad r_{t=-10}^{5} r_{j t}
$$




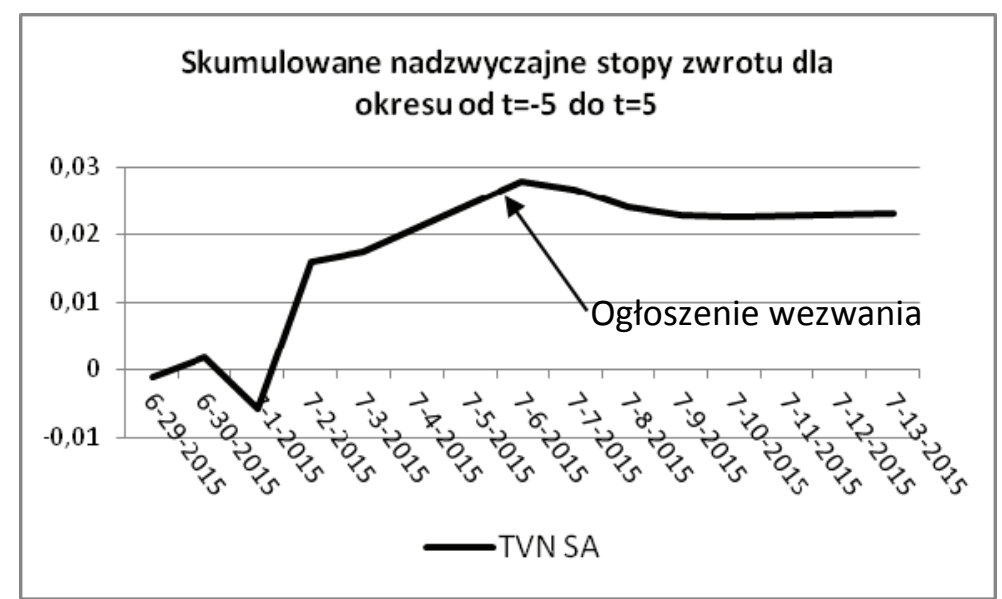

Wykres 4. Skumulowane nadzwyczajne stopy zwrotu dla akcji spółki TVN SA w okresie $5 \mathrm{dni}$

Źródło: opracowanie własne na podstawie danych z gpw.pl

Analizując wykres 4 oraz dane za okres od $\mathrm{t}=-5$ do $\mathrm{t}=5$, uzyskano skumulowaną nadzwyczajną stopę zwrotu w wysokości 2,3\%. Wynika z tego, że inwestorzy którzy dokonali transakcji kupna walorów spółki TVN SA tuż przed ogłoszeniem wezwania, mogli liczyć na zysk nadzwyczajny.

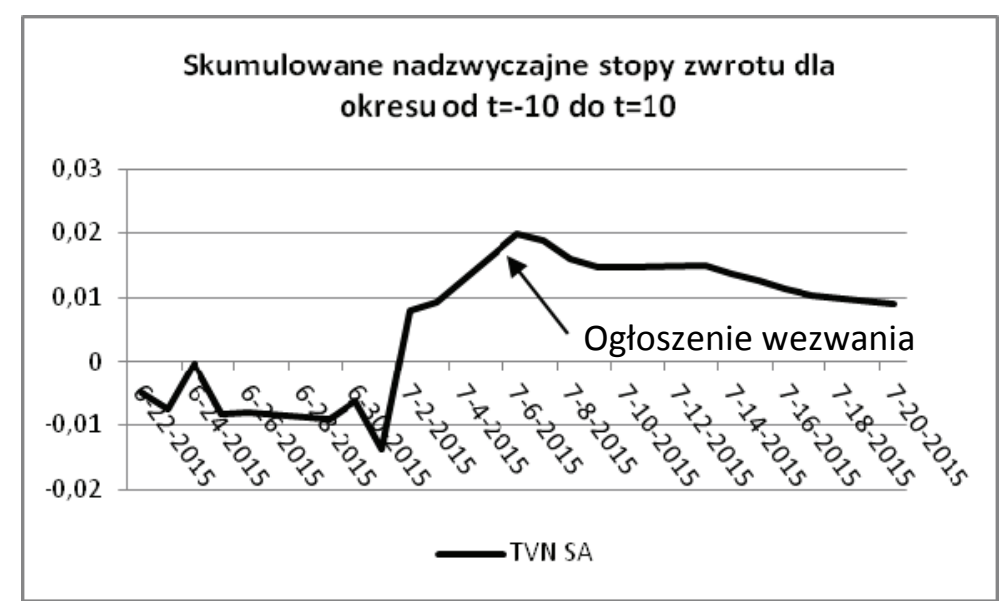

Wykres 5. Skumulowane nadzwyczajne stopy zwrotu dla akcji spółki TVN SA

w okresie $10 \mathrm{dni}$

Źródło: opracowanie własne na podstawie danych z gpw.pl

Analizując wykres 5 oraz dane za okres od $\mathrm{t}=-10$ do $\mathrm{t}=10$, uzyskano skumulowaną nadzwyczajną stopę zwrotu w wysokości $0,9 \%$. W tym przypadku stopa 
zysku nadzwyczajnego jest niższa niż stopa zysku nadzwyczajnego z okresu \pm 5 dni. Wpływ na to miał wcześniejszy spadek cen akcji spółki TVN SA w oczekiwaniu na ogłoszenie wezwania.

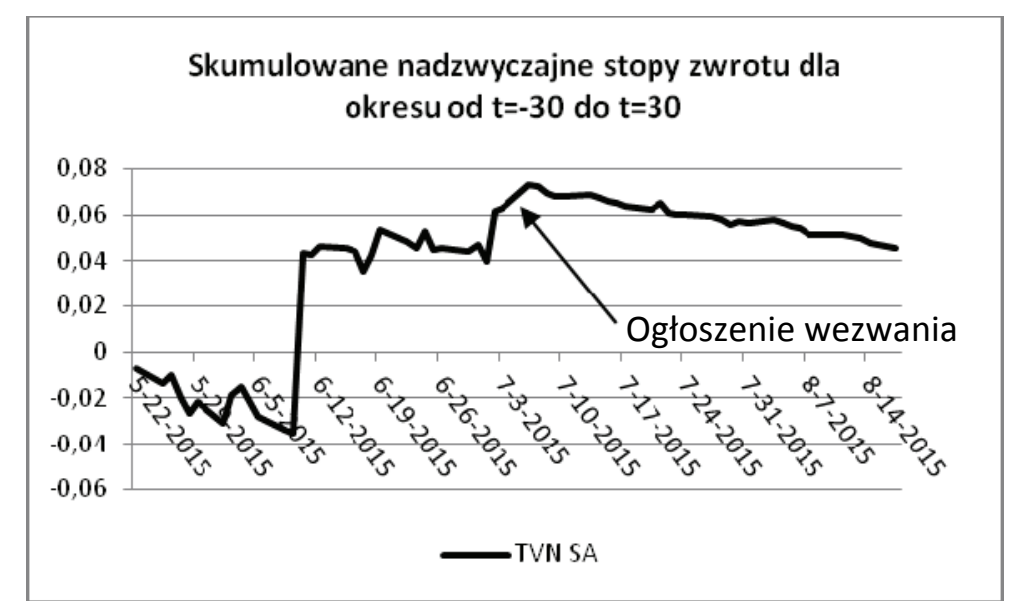

Wykres 6. Skumulowane nadzwyczajne stopy zwrotu dla akcji spółki TVN SA w okresie $30 \mathrm{dni}$

Źródło: opracowanie własne na podstawie danych z gpw.pl

Analizując wykres 6 oraz dane za okres od $\mathrm{t}=-30$ do $\mathrm{t}=30$, uzyskano skumulowaną nadzwyczajną stopę zwrotu $\mathrm{w}$ wysokości $4,6 \%$. Była to najwyższa skumulowana stopa zwrotu spośród analizowanych okresów. Według badań Lewandowskiego, który przytacza m.in. wyniki nadzwyczajnych stóp zwrotu dla firm nabywanych na rynku amerykańskim, stopy te w przypadku fuzji i przejęć wynoszą od $20 \%$ do $35 \%$ [Lewandowski, 2001]. Zatem nadzwyczajna stopa zwrotu w wysokości $4,6 \%$ dla inwestorów trzymających akcje TVN SA przez okres $\mathrm{t}= \pm 30$ dni na rynku polskim nie jest wygórowana w stosunku do rynku amerykańskiego. Jednocześnie w tym kontekście premia jaką musiała zapłacić spółka Scripps Networks Interactive za przejęcie TVN SA również nie wydaje się być zbyt wygórowana. Trzeba jednak zaznaczyć, że badania Lewandowskiego przeprowadzone były dla rynku amerykańskiego.

\section{Podsumowanie}

Przeprowadzone badania wykazały, że inwestorzy posiadający akcje spółki TVN SA mieli okazje do uzyskania nadzwyczajnych stóp zwrotu w wyniku wezwania do sprzedaży akcji ogłoszonego przez spółkę Scripps Networks Interactive. Jednocześnie spółka przejmująca chcąc pozyskać aktywa spółki TVN SA, które można zaliczyć do kategorii dóbr informacyjnych, musiała zapłacić premię dotychczasowym inwestorom, ponad kurs akcji z okresu sprzed wezwania. Nawet z obecna premia za przejęcie, spółka 
Scripps Networks Interactive dokonując transakcji nabycia ugruntowanej marki telewizyjnej $\mathrm{w}$ Polsce, wraz $\mathrm{z}$ szeregiem towarzyszących jej programów i stron internetowych wydaje się ponosić mniejsze ryzyko niepowodzenia, niż w przypadku podjęcia próby budowy sieci od podstaw. Średnie skumulowane nadzwyczajne stopy zwrotu przedstawione na wykresach 4, 5 i 6 pokazują jak zmieniały się ceny akcji spółki TVN SA w antycypacji na ogłoszenie wezwania do ich sprzedaży. Wykresy obrazują, że wraz z ogłoszeniem wezwania inwestorzy mogą spodziewać się dodatkowego dochodu będącego wynikiem wezwania. Analiza wykazuje, że publiczne ogłoszenie wezwania do sprzedaży akcji wywołuje wyraźny wzrost stopy zwrotu, znacząco poprawiając zyski akcjonariuszy. Ale co ciekawsze, jak wykazuje analiza największy przyrost wartości dla akcjonariuszy nastapił jeszcze przed ogłoszeniem wezwania do sprzedaży, znamienne jest również to, że sam wzrost wartości akacji spółki TVN SA nie był płynny lecz następował skokowo $\mathrm{w}$ dwóch etapach. W przypadku tej spółki wysoki wzrost nadzwyczajnych skumulowanych stóp zwrotu nastapił na 4 dni przed ogłoszeniem wezwania do sprzedaży, czyli $w$ okresie od $t=-5$ do $t=5$. Jeszcze bardziej znaczący skok nadzwyczajnych skumulowanych stóp zwrotu nastąpił 22 dni przed ogłoszeniem wezwania, czyli w okresie $\mathrm{t}=-30$ do $\mathrm{t}=30$, co może świadczyć o tym, że inwestorzy przewidywali i obstawiali pozytywne zakończenie negocjacji o przejęciu spółki. Innym wyjaśnieniem tego zjawiska, może być fakt trudnego ukrycia negocjacji handlowych w środowisku rozmów międzynarodowych i wykorzystanie tej sytuacji przez insiderów. Można zatem wyciagnąć wniosek, że inwestorzy antycypują w pewnym stopniu przyszłe zachowania rynku, dlatego zmiany cen akcji następują wcześniej niż wezwanie do sprzedaży.

\section{Bibliografia}

Bakos J., Brynjolfsson E., Aggregation and Disaggregation of Information Goods: Implications for Bundling, Site Licensing and Micropayment Systems, MIT Press. In press, 1997, [Tryb dostępu] http://people.stern.nyu.edu/bakos/aig.pdf [data dostępu] 14.10.2015

Kamiński J, Komorowski J, Hipoteza rynku efektywnego w chaosie rzeczywistości gospodarczej, Studia i Prace Kolegium Zarządzania Finansów, Zeszyt Naukowy 97, SGH w Warszawie, 2010, s. 9

Kraciuk J., Rola fuzji i przejęć w procesach koncentracji w polskim przemyśle spożywczym, Wydawnictwo SGGW, Warszawa 2010, s.18

Lewandowski M., Fuzje i przejęcia w Polsce na tle tendencji światowych, WIG-Press, 2001, s.145 Neuman A., Fusionen und fusionsahnliche Unternehmenszusammenschlusse unter besonderer Berucksichtigung finanzieller Aspekte, P. Haupt. Bern, 1994

Ślepaczuk R., Anomalie rynku kapitałowego w świetle hipotezy efektywności rynku, Katedra Bankowości i Finansów, Wydział Nauk Ekonomicznych, Uniwersytet Warszawski 2006, [Tryb dostępu] http://www.e-finanse.com/artykuly/41.pdf [data dostępu] 14.10.2015

Varian Hal R., Markets for Information Goods, 1998 [Tryb dostępu] http://people.ischool.berkeley.edu/ hal/Papers/japan/japan.html\#SECTION000200000000000000 00 [data dostępu] 14.10.2015 


\section{Summary}

This paper investigates through a case study, the acquisition of TVN SA company by Scripps Networks Interactive Inc. The material presented discusses the impact of the acquisition on profits of investors who held shares of the company in different periods of time. Since both companies represent the sector of information economy, the article starts with the definition of information goods, and the main characteristics of the industry. Information goods are often characterized by short product life cycle. For this reason, companies operating in this sector often face the dilemma of make/buy decision for a product. Due to the nature of information goods and the role that sunk costs play in the development of such goods, organic growth in the information goods sector, especially in new geographic location entails a high risk of failure. On the other hand, the acquisition of a company with a finished product often involves paying a premium. The aim of the article was to examine how a call for take-over in the information goods industry impacts the profits of investors holding shares in different periods of time, and what premium for the acquisition has to be paid by the acquiring company.

Key words: information goods, mergers, acquisitions, industry concentration, rate of return

Informacja o autorze:

Adam Andrzejuk

Szkoła Główna Gospodarstwa Wiejskiego w Warszawie

Katedra Ekonomiki Rolnictwa i Międzynarodowych Stosunków Gospodarczych

ul. Nowoursynowska 166, 02-787 Warszawa

e-mail: adam_andrzejuk@sggw.pl 